\title{
Introduction: geodynamic evolution of the Zagros
}

\author{
OLIVIER LACOMBE*, BERNHARD GRASEMANN $\dagger \&$ GUY SIMPSON $\ddagger$ \\ *Université Pierre et Marie Curie, Institut des Sciences de la Terre de Paris, Paris, France \\ $\dagger$ University of Vienna, Department for Geodynamics and Sedimentology, Vienna, Austria \\ $\ddagger$ University of Geneva, Department of Geology and Palaeontology, Geneva, Switzerland
}

This special issue of Geological Magazine presents a collection of 17 papers dealing with different aspects of the Zagros orogen. Many, though not all, of these contributions were presented as part of a highly successful session devoted to the geodynamic evolution of the Zagros belt at the European Geosciences Union General Assembly 2010 in Vienna (Austria). The aim of this gathering was to assemble a broad group of Earth scientists interested in the Zagros orogen to discuss and disseminate new results and ideas efficiently. This volume presents a collection of some of the diverse research that is currently being carried out in the Zagros. We believe that these studies contribute to the understanding of the geodynamic evolution of the Zagros Mountains in particular, but in addition to orogenic processes in general.

The Zagros mountain belt extends over $1800 \mathrm{~km}$ from Kurdistan in N Iraq to the Strait of Hormuz in Iran and results from the long-standing and ongoing convergence between the Eurasian and Arabian plates, during which time the Neo-Tethys oceanic basin was closed. The Zagros region contains a large part of global fold-and-thrust belt-related hydrocarbons, which are related to antiformal structures. These giant whaleback anticlines form spectacular geomorphic structures, some of which interact with huge salt diapirs and glaciers. Additionally, the Zagros is famous for its seismic activity and active deformation.

A lot of work has been carried out on the Zagros Mountains during the last decade, and many new and exciting results have been (and are currently being) obtained. This research concerns in particular GPS measurements, field studies dealing with active deformation and kinematics, new age dating of synorogenic deposits or new time constraints on the rates of slip along the main active faults of the Zagros and its hinterland, magmatism-metamorphismexhumation of the hinterland, as well as evolution of topography and landscape morphology related to climatic, eustatic and/or tectonic controls. Despite this wealth of recent data, many poorly documented or unanswered questions remain, some of which are investigated in this issue:

(1) How did topography, deformation and distribution of depocentres of the Zagros orogenic system evolve through time? Walker, Ramsey \& Jackson (2011) reconstruct ancient drainage systems in the Fars region from geomorphic patterns, and relate drainage evolution to patterns of thrust belt migration and the expansion of the Iranian plateau.

(2) What was the geometry and makeup of the former Arabian margin? Verges et al. (2011) provide a quantified balanced crustal cross-section across the NW Zagros by integrating geological and geophysical local and global datasets. This section is restored using different tectonosedimentary domains according to their sedimentary facies and palaeobathymetries, thus providing new first-order constraints on the geometry of the former Arabian passive margin as well as new estimates of amount and rate of shortening for both the cover rocks and the Arabian basement, including all compressional events from Late Cretaceous to Recent times.

(3) How is subduction recorded in the Zagros? After a synthetic overview of the geodynamic evolution of the Zagros orogen within the frame of the Arabia-Eurasia collision, Agard et al. (2011) provide lithospheric-scale reconstructions of the Zagros orogen since Jurassic time across two SW-NE transects and compare the evolution of the Zagros orogen to those of the nearby Turkish and Himalayan orogens. Their reconstructions underline the key role played by subduction throughout the whole convergence history.

(4) What role did inheritance play in explaining along-strike variations in Zagros geology? Allen \& Talebian (2011) discuss the nature of the Dezful Embayment by means of review of fault patterns and isopach maps, concluding that this area has been a depocentre since roughly $35 \mathrm{Ma}$, i.e. the likely time of initial collision between Arabia and Eurasia. They propose that the syn-collision structure and stratigraphy of the Zagros is strongly influenced by the variation in Late Cretaceous ophiolite emplacement. Karim et al. (2011) present two newly discovered angular unconformities in the Mesozoic-Cenozoic succession in the NW Zagros fold-thrust belt in the Kurdistan region of Iraq. The unconformities are attributed to the ophiolite emplacement recording diachronous deposition and different deformation/exhumation/erosion histories of the Mesozoic-Cenozoic sedimentary units. Lacombe, Bellahsen \& Mouthereau (2011) investigate the early collisional tectonic history in the Simply Folded Belt of the Fars arc using the analysis of fracture sets combined 
with palaeostress reconstructions based on fault-slip data. Their work highlights the need to carefully consider pre-existing fractures unrelated to folding but possibly controlled by (reactivated) basement faults, which may significantly influence further development of new fracture sets.

(5) What is the makeup of the Zagros foreland basin and how did it evolve through time? Pirouz et al. (2011) investigate Neogene deposits of the Zagros foreland basin and derive a southward migration of foreland basin depo-zones as the Zagros fold-thrust belt migrated progressively southward towards the Arabian foreland. They emphasize that this vertical succession bears a striking similarity to modern depositional environments and sedimentary deposits observed in the Zagros region today, which suggests that the major Neogene formations of the Zagros foreland basin are strongly diachronous and have active modern-day equivalents.

(6) How, and by which mechanisms, is convergence distributed and accommodated in space and time and what controls deformation kinematics? Mouthereau (2011) suggests that during the past $22 \mathrm{Ma}$ stable motion of Arabia, a shift of localized deformation occurred in Late Miocene-Pliocene times towards the Zagros or the Alborz that were uplifting, and that a concomitant decrease of shortening rates in the Iranian plateau occurred to compensate for constant boundary velocity. Abdollahie Fard, Sepehr \& Sherkati (2011) demonstrate that the evaporitic sequence plays an important role in sealing the Oligocene-Miocene Asmari reservoirs in the Dezful Embayment and offshore regions. They document rapid and important thickness changes related to faulting, folding and flow. Trocmé et al. (2011) build a threedimensional structural model of parts of the Fars region by integrating topography, geological surface data, well data and seismics. The main insights of this modelling are the better definition of the depth to basement, and the pre-salt morphology, the geometry at depth of salt diapirs and the interaction between salt diapirism and folding. Tavani et al. (2011) analyse mesoscopic deformation pattern of the Bangestan anticline (SW Zagros, Iran) and discuss its relationships with the kinematic evolution of the hosting structure. They conclude that anticlines in the Simply Folded Belt provide excellent exposed analogue structures for fractured reservoirs located in the more external sectors of the belt. Faghih \& Sarkarinejad (2011) presents quantitative structural data on the finite strain, quartz textures and the flow fabric in deformed quartzite samples in order to characterize the ductile deformation within the Sanandaj-Sirjan Metamorphic Belt in Iran. The data indicate that deformation within this belt involved top-to-the-SE-directed general non-coaxial flow with contemporaneous contributions of pure and simple shear. Shaban, Sherkati \& Miri (2011) perform strain and curvature analysis of the Gachsaran oil field and use these results to understand better the field's reservoir performance.
(7) What is the nature and origin of magmatism and ophiolites in the Zagros hinterland? Aswad, Aziz \& Koyi (2011) explore the chemical characteristics of chrome spinels of the northwestern Zagros Suture Zone in Kurdistan. They propose that the presence of two groups of distally separated serpentinites with different emplacement-age and fore-arc tectonic affinity could indicate that the closure of the Tethys Ocean culminated in two fortuitous subduction processes. In a companion paper, Aziz, Aswad \& Koyi (2011) investigate serpentinites from the Zagros Suture Zone in the Kurdistan region of Iraq. Geochemical data clearly discriminate between two groups of serpentinites, which might reflect the subduction of different sedimentary sequences and mixing of the components with the mantle wedge. Aziz, Aswad \& Koyi suggest a complex multi-stage emplacement of serpentinite units on the Arabian platform sediments. Shafaii Moghadam \& Stern (2011) review the Upper Cretaceous ophiolites of the Zagros, and conclude that both the inner belt and outer belt originated in a single fore-arc tract, which was later disrupted by the exhumation of subducted metamorphic rocks. Aghazadeh et al. (2011) describe the Shaivar Dagh plutonic complex, and conclude that subduction-related magmatism fertilized the source region of magmas that postdate initial continental collision.

Many of these questions are only just beginning to be addressed and the possibilities for future work in this region appear unlimited. In comparison to many other more extensively documented orogens such as the European Alps, the Zagros remains somewhat of a frontier where scientists can continue to address fundamental questions and collect basic data pertaining to the evolution of convergent orogens.

Acknowledgements. We would like to acknowledge the reviewers who have played an important part in maintaining a high level of rigour to the contributions. Journal Editor Mark Allen is warmly thanked for his kind and valuable help during the review process.

\section{References}

Abdollahie Fard, I., Sepehr, M. \& Sherkati, S. 2011. Neogene salt in SW Iran and its interaction with Zagros folding. Geological Magazine 148, 854-67.

Agard, P., Omrani, J., Jolivet, L., Whitechurch, H., VRielynck, B., Spakman, W., Monié, P., Meyer, B. \& WORTEL, R. 2011. Zagros orogeny: a subductiondominated process. Geological Magazine 148, 692725 .

Aghazadeh, M., Castro, A., Badrzadeh, Z. \& Vogt, K. 2011. Post-collisional polycyclic plutonism from the Zagros hinterland: the Shaivar Dagh plutonic complex, Alborz belt, Iran. Geological Magazine 148, 980-1008.

Allen, M. B. \& TALEBIAN, M. 2011. Structural variation along the Zagros and the nature of the Dezful Embayment. Geological Magazine 148, 911-24.

AswAD, K. J. A., AZIZ, N. R. H. \& KoYI, H. A. 2011. Cr-spinel composition in serpentinites and their implications for the petrotectonic history of the Zagros Suture Zone, Kurdistan Region, Iraq. Geological Magazine 148, 80218. 
AzIZ, N. R. H., Aswad, K. J. A. \& KoYI, H. A. 2011. Contrasting settings of serpentinite bodies in the northwestern Zagros Suture Zone, Kurdistan Region, Iraq. Geological Magazine 148, 819-37.

FAGHIH, A. \& SARKARINEJAD, K. 2011. Kinematics of rock flow and fabric development associated with shear deformation within the Zagros transpression zone, Iran. Geological Magazine 148, 1009-17.

Karim, K. H., Koyi, H., BaZiany, M. M. \& Hessami, K. 2011. Significance of angular unconformities between Cretaceous and Tertiary strata in the northwestern segment of the Zagros fold-thrust belt, Kurdistan Region, NE Iraq. Geological Magazine 148, 92539.

Lacombe, O., Bellahsen, N. \& Mouthereau, F. 2011. Fracture patterns in the Zagros Simply Folded Belt (Fars, Iran): constraints on early collisional tectonic history and role of basement faults. Geological Magazine 148, 940-63.

MouthereaU, F. 2011. Timing of uplift in the Zagros belt/Iranian plateau and accommodation of late Cenozoic Arabia-Eurasia convergence. Geological Magazine 148, 726-38.

Pirouz, M., Simpson, G., BAHroudi, A. \& AzhDARI, A. 2011. Neogene sediments and modern depositional environments of the Zagros foreland basin system. Geological Magazine 148, 838-53.
Shaban, A., Sherkati, S. \& Miri, S. A. 2011. Comparison between curvature and 3D strain analysis methods for fracture prediction in the Gachsaran oil field (Iran). Geological Magazine 148, 868-78.

Shafail MoghadAM, H. \& SteRn, R. J. 2011. Geodynamic evolution of Upper Cretaceous Zagros ophiolites: formation of oceanic lithosphere above a nascent subduction zone. Geological Magazine 148, 762-801.

TAVAni, S., StORTi, F., SOlEimany, B., FALlah, M., MuÑoz, J. A. \& GAMBINI, R. 2011. Geometry, kinematics and fracture pattern of the Bangestan anticline, Zagros, SW Iran. Geological Magazine 148, 964-79.

Trocmé, V., Albouy, E., Callot, J.-P., Letouzey, J., Rolland, N., GoODARZI, H. \& JAHANI, S. 2011. 3D structural modelling of the southern Zagros fold-andthrust belt diapiric province. Geological Magazine 148, 879-900.

Vergés, J., Saura, E., Casciello, E., Fernandez, M., VillaseÑor, A., JimeneZ-Munt, I. \& GARCIACAstellanos, D. 2011. Crustal-scale cross-sections across the NW Zagros belt: implications for the Arabian margin reconstruction. Geological Magazine 148, 73961.

WALKeR, R. T., RAMSEY, L. A. \& JACKSON, J. 2011. Geomorphic evidence for ancestral drainage patterns in the Zagros Simple Folded Zone and growth of the Iranian plateau. Geological Magazine 148, 901-10. 